\title{
Application of Amino Transaminases in a Disperse System for the Biotransformation of Hydrophobic Substrates
}

\author{
Andrea Fiorati, ${ }^{\text {a }}$ Per Berglund, ${ }^{\mathrm{b}}$ Maria Humble, ${ }^{\mathrm{b}, \mathrm{c}}$ Davide Tessaro ${ }^{\mathrm{a}, *}$ \\ a Politecnico di Milano, Department of Chemistry, Materials and Chemical Engineering “G. Natta”, p.za L. da Vinci 32, \\ I-20133 Milano, Italy \\ E-mail: davide.tessaro@polimi.it \\ b KTH Royal Institute of Technology, School of Engineering Sciences in Chemistry, Biotechnology and Health (CBH), \\ Department of Industrial Biotechnology, AlbaNova University Center, SE-10691 Stockholm, Sweden \\ c Pharem Biotech AB, Biovation Park, Forskargatan 20 J, SE-15136 Södertälje, Sweden
}

Received: ((will be filled in by the editorial staff))

Supporting information for this article is available on the WWW under http://dx.doi.org/10.1002/adsc.201\#\#\#\#\#\#.((Please delete if not appropriate))

\begin{abstract}
The challenging bioamination of hydrophobic substrates has been attained through the employment of a disperse system consisting in a combination of a low polarity solvent (e.g. isooctane or MTBE), a non-ionic surfactant and a minimal amount of water. In these conditions, good conversions are achieved, often coupled with a superior stereoselectivity if compared with the corresponding chemical reductive amination.
\end{abstract}

\begin{abstract}
An array of synthetically useful 4-substituted aminocyclohexanes was consequentially synthesized and stereochemically characterized.
\end{abstract}

Keywords: Bioamination; biocatalysis; reductive amination; disperse systems

\section{Introduction}

Variously substituted 4-cyclohexylamines are important building blocks in medicinal chemistry, and a selective general synthesis for this class of compounds would be of major importance among the research chemists. ${ }^{[1]}$ Here, a biocatalytic approach for the stereoselective conversion of 4,4-disubstituted cyclohexanones into the corresponding amines using amine transaminases (ATAs, EC 2.6.1) as biocatalysts (Scheme 1) is presented. The reactions are run in an unusual disperse system in order to overcome the solubility issues associated with such hydrophobic substrates.

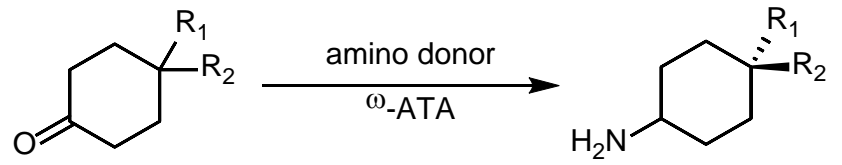

Scheme 1. Biocatalytic reductive amination of achiral cyclohexanone derivatives.

The reactions catalyzed by ATAs are commonly carried out in aqueous media, often in combination with a minor amount of hydrophilic solvents (e.g. DMSO) when an increase in solubility of an organic substrate is sought. In contrast, there are only a few reports covering the application of ATAs in pure organic solvents. ${ }^{[2]}$ The first ATA successfully employed in a substantial amount of organic solvent (i.e. 50 \% DMSO) was reported in 2010 for the synthesis of Sitagliptin, ${ }^{[3]}$ where the immobilization of the enzyme permitted even the employment of neat organic solvents. ${ }^{[4]}$ Since then, other isolated reports on immobilized transaminases have been published. However, the obtained results suggest that the biocatalyst activity in organic medium is not substantially enhanced as a result of the immobilization. The main drawbacks may be related to mass transfer problems or to the scarce solubility of the cofactor (pyridoxal 5'-phosphate, PLP) in organic solvents. ${ }^{[5]}$

Recently, the application of some lyophilized ATAs in ethyl acetate and methyl-tert-butyl ether (MTBE) was shown. ${ }^{[2 a]}$ Increased stability of the enzyme and the absence of substrate inhibition were underlined. The key factor of this work is the activity of water in the organic medium; this is in line with the generally accepted mechanism of transamination, ${ }^{[6]}$ where a water molecule is involved in the catalytic cycle. The same authors also report on the use of this approach in the stereoselective synthesis of valinol, ${ }^{[7]}$ and for 3-substituted cyclohexylamine derivatives. ${ }^{[8]}$ The use of surfactants (i.e. Brij ${ }^{\circledR} \mathrm{C} 10$ and octyl $\beta$-D-glucopyranoside) as an additive prior to the lyophilization of the enzyme for employment in organic solvent was recently reported for the biocatalytic reductive amination of methoxyacetone. In that study, the ATA from 
Chromobacterium violaceum ( $\mathrm{Cv}$-ATA) was applied as a suspension of surfactant-stabilized lyophilized powder for the stereoselective conversion of methoxyacetone to the corresponding amine in dry isooctane employing (S)-phenylethylamine ((S)-PEA) as amino donor (Scheme 2). ${ }^{[9]}$

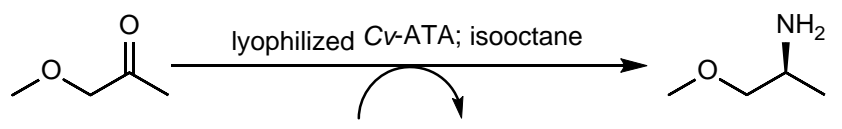

(S)-PEA Acetophenone

Scheme 2. Synthesis of 3-methoxy-2-(S)-propylamine.

Unfortunately, we experienced how this approach leads to unsatisfactory results when applied to 4substituted-cyclohexanones, in particular in terms of reaction rate. In order to address this issue, a novel approach for the application of ATAs in organic solvents was developed. In this procedure, an aqueous solution of the enzyme, a non-ionic surfactant, the substrate, and an appropriate organic solvent are mixed together to form a macroscopically homogeneous system. Such procedure was successfully applied to the reductive amination of a library of hydrophobic 4,4-disubstituted cyclohexanones using different ATAs, and lead to interesting results also in terms of stereoselectivity.

\section{Results and Discussion}

At first, following the procedure given in ref. [9], $\mathrm{Cv}$-ATA was employed as a surfactant-stabilized powder in dry isooctane at $37{ }^{\circ} \mathrm{C}$ using 4-tert-butylcyclohexanone (1a) as a model substrate (Scheme 3). This resulted in a very low reaction rate, and only $40 \%$ conversion was observed after 8 days. On the other hand, the diastereomeric ratio (24/76 cis/trans) of the newly formed amine was the opposite with respect to the product obtained through metalmediated reductive amination. ${ }^{[10]}$

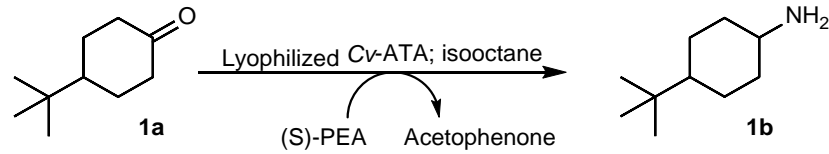

Scheme 3. Model reaction: enzymatic amination of 4-tertbutylcyclohexanone (1a).

A MS analysis of the crude reaction mixture showed that $(S)$-PEA spontaneously reacted with the substrate giving the corresponding Schiff base as a by-product; this reaction is reasonably favored by the low water activity in the reaction media. Despite the reversibility of the Schiff base formation, the depletion of the ketone from the mixture is probably responsible for the reduction of the reaction rate and, consequentially, of the overall conversion. In order to increase the reaction efficiency, we tried at first to tune the reaction parameters, in particular focusing on the lyophilization time and the water activity in the solvent. Indeed, an increase of the freeze-drying time brings some beneficial effects in terms of catalyst activity (See SI), even if the reaction rate still results too low to be of any practical use. Since the water activity in the organic solvent generally plays a major role in the enzyme performance, the effect of small additions of water into the reaction mixture was explored and established to have, indeed, some beneficial effects on both the reaction rate and the final conversion, also by preventing the imine formation, as demonstrated by GC-MS (data not shown). However, the high hydrophobicity of isooctane allows the addition of only a tiny amount of water before a new liquid phase appears, preventing an efficient mixing of the components and complicating the downstream processing.

As an alternative approach stemming from the same components, we designed a ternary reaction mixture containing a hydrophobic organic solvent, a small amount of water and an appropriate surfactant, with the aim to generate amphiphilic supramolecular assemblies. Such systems have been extensively described in the 80 s by Luisi and coworkers, ${ }^{[11]}$ and are based on the formation of reverse micelles encapsulating the enzyme. Thus, a water-in-oil disperse environment suitable for ATAs was designed and employed. According to literature, in this work, we refer to micelles (oil in water) and reverse micelles (water in oil) when the assemblies dimensions are around 5-10 nm, microemulsions when droplets dimensions are 10-100 nm and emulsions when the droplets size ranges 0.5-200 $\mathrm{mm} .{ }^{[12]}$ Briefly, a non-ionic surfactant (e.g. Polyethylene-glycolhexadecyl-ether, Brij ${ }^{\circledR} \mathrm{C} 10$ ) is at first dissolved in a hydrophobic organic solvent (isooctane or MTBE) together with the substrates at $37^{\circ} \mathrm{C}$. After complete dissolution, a small amount of aqueous enzymatic preparation ( $1 \% \mathrm{v} / \mathrm{v})$ was added to the reaction mixture and then vigorously shaken. In order to find suitable reaction conditions for screening our library of ketones, a model transamination system was explored with the use of 1a (25 mM), (S)-PEA, Brij ${ }^{\circledR} \mathrm{C} 10$ (as surfactant) and $\mathrm{Cv}$-ATA $(0.95 \mathrm{U})$ as biocatalyst. Through a preliminary characterization of the system, the following parameters were evaluated: donor/acceptor ratio, nature of organic solvent and surfactant, reaction temperature, nature of amino donor.

When the reaction solvent is isooctane and the surfactant employed is Brij ${ }^{\circledR} \mathrm{C} 10(50 \mathrm{mM})$ at $37{ }^{\circ} \mathrm{C}$ 
the reaction mixture is perfectly clear and transparent; the addition of $1.0 \% \mathrm{v} / \mathrm{v}$ of the aqueous enzymatic preparation, upon vigorous shaking, turns the mixture into a macroscopically homogeneous milky emulsion; this mixture is stable as long as the necessary agitation is provided. Interruption of the shaking leads to phase separation and to a drastic slowdown of the conversion rate. On the other hand, when employing no more than $0.2 \% \mathrm{v} / \mathrm{v}$ of water, a stable, transparent and clear solution is obtained. In this case, we assume that such a configuration may be considered as a micellar system, where the enzyme solution is entrapped in thermodynamically stable reverse micelles. Such a hypothesis is confirmed by DLS experiments (Figure 1, green peaks), which show that the reaction system is composed of a homogeneous population of particles with a mean hydrodynamic radius of $16 \mathrm{~nm}$.

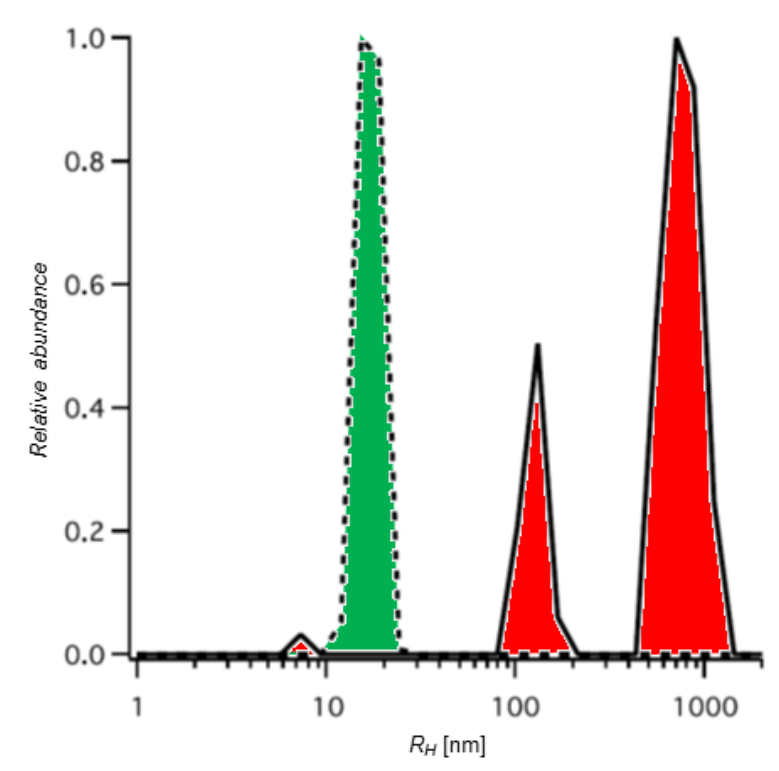

Figure 1. Mean hydrodynamic radius distributions of the particles obtained using $50 \mathrm{mM}$ of Brij ${ }^{\circledR} \mathrm{C} 10$ in isooctane at $37^{\circ} \mathrm{C}$. Dashed line, green peaks: $0.2 \% \mathrm{v} / \mathrm{v}$ of aqueous enzymatic preparation. Continuous line, read peaks: $1.0 \%$ of aqueous enzymatic preparation.

This is consistent with the hypothesis of a solution containing spherical inverse micelles with a confined aqueous phase encapsulating the enzyme, as illustrated in the literature. ${ }^{[11]}$ An increase of the buffer concentration leads to a destabilization of the micelles, which coalesce in droplets and form an emulsion stabilized by the surfactant (Figure 1, red peaks). When isooctane is substituted with MTBE, DLS analysis indicates the presence of two supramolecular populations, the former on a nanometric scale and the latter in the range of hundreds of $\mathrm{nm}$, even employing a small amount $(0.2 \% \mathrm{v} / \mathrm{v})$ of aqueous solution (data shown in SI).
According to the aforesaid definitions, the system should be in this case described as an emulsion, even though the mixture looks macroscopically like a transparent and clear solution. The different assemblies are summarized in Table 1

Table 1. Effect of water concentration on the system selfassembly. Micelles shape is based on the measured hydrodynamic radius and is only speculative. Conditions: $25 \mathrm{mM}$ ketone 1a; $50 \mathrm{mM}(S)-P E A ; 50 \mathrm{mM}$ decane; 50 $\mathrm{mM}$ Brij ${ }^{\circledR}$ C10. A proper amount of Hepes buffer $50 \mathrm{mM}$ containing (or not) $13 \mathrm{mg} / \mathrm{mL}$ of $\mathrm{Cv}$-ATA has been added.

\begin{tabular}{|c|c|c|c|}
\hline \multirow{2}{*}{$\begin{array}{c}\text { Water } \\
\text { concentration } \\
v / v[\%]\end{array}$} & \multirow{2}{*}{ Enzyme } & \multicolumn{2}{|c|}{ Solvent } \\
\hline & & isooctane & MTBE \\
\hline 0 & No & $\begin{array}{l}\text { Spheric } \\
\text { micelles }\end{array}$ & $\begin{array}{c}\text { Oblong } \\
\text { micelles }\end{array}$ \\
\hline 0.2 & No & $\begin{array}{l}\text { Spheric } \\
\text { micelles }\end{array}$ & $\begin{array}{c}\text { Stable } \\
\text { emulsion }\end{array}$ \\
\hline 0.2 & Yes & $\begin{array}{l}\text { Spheric } \\
\text { micelles }\end{array}$ & $\begin{array}{c}\text { Stable } \\
\text { emulsion }\end{array}$ \\
\hline 1.0 & Yes & $\begin{array}{c}\text { Stable } \\
\text { emulsion }\end{array}$ & $\begin{array}{l}\text { Unstable } \\
\text { emulsion }\end{array}$ \\
\hline
\end{tabular}

In order to evaluate the performances of such systems, the conversion of $\mathbf{1 a}$ to the relative amine was studied. Two different experiments were carried out employing the same amount of enzyme $(0.13 \mathrm{mg}$, $0.82 \mathrm{U}$ ) diluted in order to obtain a final concentration of the aqueous solution of 1.0 and $0.2 \% \mathrm{v} / \mathrm{v}$, respectively. A third experiment was performed using $1.0 \% \mathrm{v} / \mathrm{v}$ of the enzymatic preparation at a higher concentration $(0.45 \mathrm{mg}, 2.8 \mathrm{U})$.

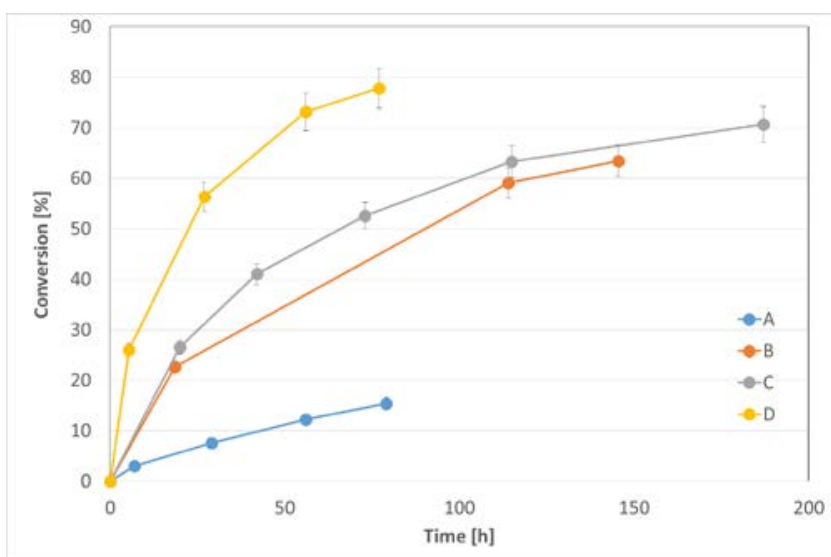

Figure 2. Effect of water content. A. $0.2 \% \mathrm{v} / \mathrm{v}$ of buffer containing $0.82 \mathrm{U} \quad \mathrm{Cv}$-ATA. B. $1.0 \% \mathrm{v} / \mathrm{v}$ of buffer containing $0.95 \mathrm{U} C v$-ATA. C. $1.0 \% \mathrm{v} / \mathrm{v}$ of buffer containing $0.95 \mathrm{U} \mathrm{Cv}$-ATA. D. $1.0 \% \mathrm{v} / \mathrm{v}$ of buffer containing $0.45 \mathrm{mg}(2.8 \mathrm{U}) \mathrm{Cv}$-ATA. Reaction conditions: $25 \mathrm{mM}$ ketone 1a; $50 \mathrm{mM}$ (S)-PEA; $50 \mathrm{mM}$ decane; 50 $\mathrm{mM}$ Brij ${ }^{\circledR} \mathrm{C} 10$; enzyme preparation in HEPES buffer $(\mathrm{pH}$ 8.2, $50 \mathrm{mM}$ ); isooctane to final volume $1 \mathrm{~mL}$. 
The results are reported in Figure 2. According to these data, the emulsion systems possess better performances when compared to the corresponding micellar systems. Moreover, as expected, employing about 3.5 times more enzyme leads to an approximately three-fold faster reaction.

Another interesting aspect is that the reaction workup results quick and easy if compared to a standard extractive protocol. By just centrifuging the cooled $\left(4{ }^{\circ} \mathrm{C}\right)$ reaction mixture it is possible to separate the organic phase, containing substrates and products, from the solids, composed by salts, enzyme, cofactor and surfactant.

The stability of $C v$-ATA in the studied reaction medium results remarkably high: the enzyme is able to retain its activity all along the explored reaction time (187 h, more than one week). The addition of a different substrate, i.e. methoxyacetone, to the solution after reaching the conversion plateau immediately reactivates the reaction: a further aliquot of (S)-PEA is consumed and the corresponding amount of acetophenone is released (Figure 3). This also demonstrates that the conversion observed at the end of the reaction depends on the assessment of the thermodynamic equilibrium and is not due to any inactivation of the enzyme.

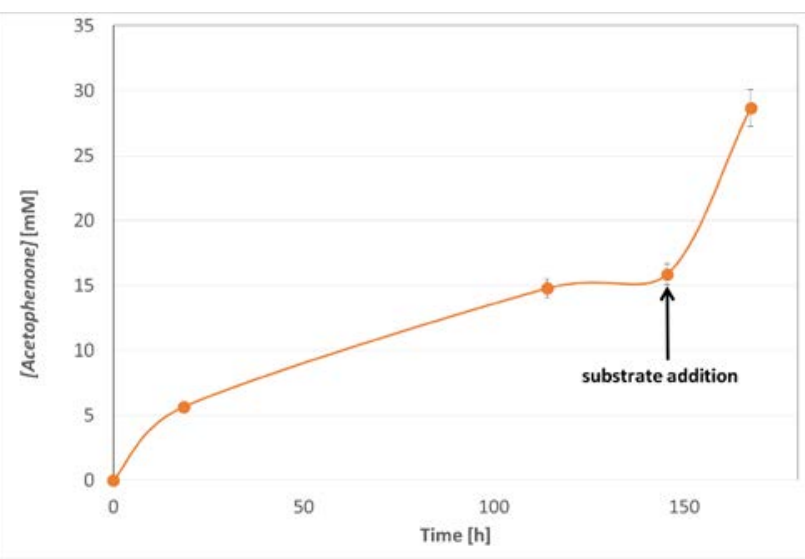

Figure 3. Stability of the enzymatic preparation: addition of methoxyacetone (25 mM) after $144 \mathrm{~h}$ of reaction. Reaction conditions: $25 \mathrm{mM}$ ketone 1a; $50 \mathrm{mM}(S)-\mathrm{PEA}$; $50 \mathrm{mM}$ decane; $50 \mathrm{mM}$ BrijR C10; $10 \mu \mathrm{L}$ enzyme preparation (0.95 U) in HEPES buffer ( $\mathrm{pH} \mathrm{8.2,} 50 \mathrm{mM})$; isooctane to final volume $1 \mathrm{~mL}$.

Figure 4 reports the results of a set of experiments aimed at investigating the influence and proper ratio between amino donor and amino acceptor. These experiments were carried out with a fixed concentration of 1a, while the concentration of (S)PEA was varied. Apparently, while a slight excess of the amino donor has a positive effect, higher concentrations of (S)-PEA lead to significant inhibition. However, for the purpose of screening the ketones library (see later) we decided to use $50 \mathrm{mM}$ of (S)-PEA in order to push the thermodynamic equilibrium towards the products. ${ }^{[13]}$ At the same time, many experiments with different amino donors have been performed, in particular using benzylamine and isopropylamine at different concentrations. Despite both amines are known in the literature for being accepted as amino donors by $C v$-ATA, ${ }^{[14]}$ no conversion was observed in all cases.

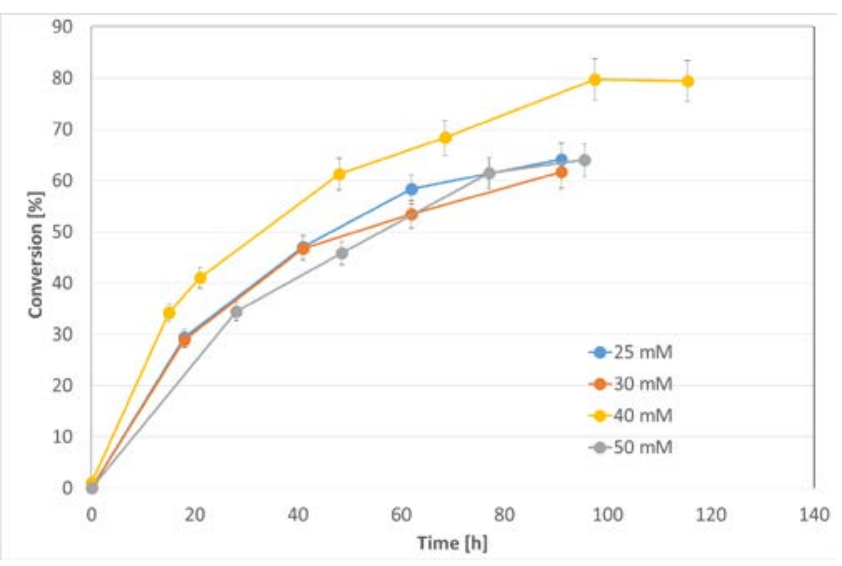

Figure 4. Influence on conversion of the ratio between ketone 1a and amino donor. Reaction conditions: $50 \mathrm{mM}$ (S)-PEA; $50 \mathrm{mM}$ decane; $50 \mathrm{mM}$ Brij ${ }^{\circledR} \mathrm{C} 10 ; 10 \mu \mathrm{L}$ of $\mathrm{Cv}$ ATA preparation (0.95 U) in HEPES buffer (pH 8.2, 50 $\mathrm{mM}) ; 37^{\circ} \mathrm{C}$; isooctane to final volume $1 \mathrm{~mL}$.

Different solvents were investigated: MTBE, isooctane, ethyl acetate (AcOEt), cyclohexane, chloroform, toluene and dimethoxyethane (DME). Among them, only DME is miscible with water. In our experiments, isooctane allows the highest conversions. Good results are also obtained using MTBE and cyclohexane, while ethyl acetate results less efficient (Figure 5).

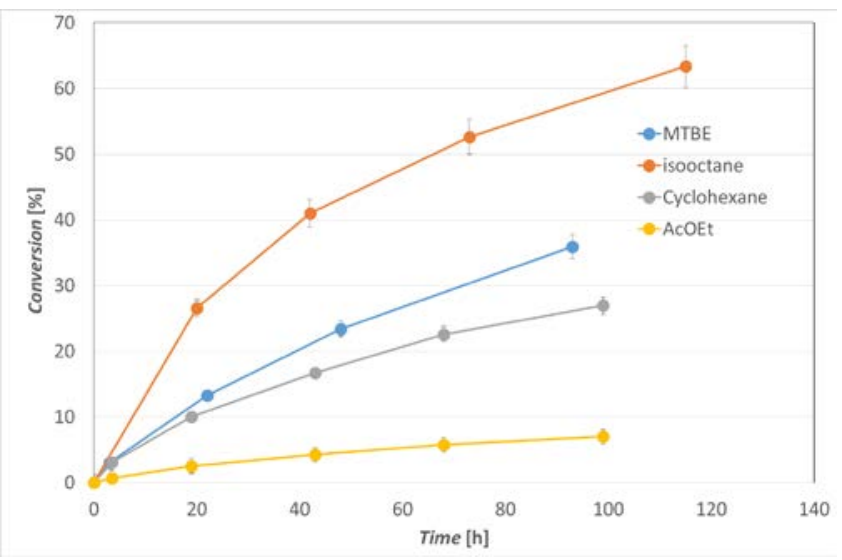

Figure 5. Influence of organic solvent. Reaction conditions: $25 \mathrm{mM}$ ketone 1a; $50 \mathrm{mM}$ (S)-PEA; $50 \mathrm{mM}$ 
decane; $50 \mathrm{mM}$ Brij c10; $10 \mu \mathrm{L}$ enzyme preparation (0.95 $\mathrm{U})$ in HEPES buffer ( $\mathrm{pH} 8.2,50 \mathrm{mM})$; $37^{\circ} \mathrm{C}$; final volume $1 \mathrm{~mL}$.

No conversion is detected using either chloroform, toluene or DME. We point out that this solvent screening was focused on improving the activity of $\mathrm{Cv}$-ATA, and the solvent tolerability may differ for other ATAs. Moreover, the identity of organic solvent might also affect the final position of reaction equilibrium.

After selecting the best performing organic solvent, the model reaction was evaluated in isooctane at different temperatures (see SI). The highest conversions are obtained at $37{ }^{\circ} \mathrm{C}$. Temperatures lower than $30{ }^{\circ} \mathrm{C}$ lead to the incomplete dissolution of $\mathrm{Brij}^{\circledR} \mathrm{C} 10$ in the medium, while higher temperatures result in lower conversions. Albeit the enzyme in other conditions shows good thermostability, ${ }^{[15]}$ it is nevertheless known that the presence of (S)-PEA significantly lowers its melting point. $^{[9,}$ 16] This fact, in combination with the particular environment we describe, might explain the thermal inactivation we observed.

Table 2. Employed surfactants. AOT stands for Aerosol OT, or dioctyl sodium sulfosuccinate.

\begin{tabular}{llc}
\hline Surfactant & Type & HLB \\
\hline Brij $^{\circledR}$ C10 & Non-ionic & 12.0 \\
Triton $^{\text {TM }}$ X-100 & Non ionic & 13.5 \\
Brij $^{\circledR} 58$ & Non-ionic & 15.7 \\
Tween $^{\circledR} 20$ & Non-ionic & 16.7 \\
AOT & Ionic & - \\
\hline
\end{tabular}

Once set up the reaction conditions, five different surfactants were investigated (Table 2, structures in SI). The surfactants were evaluated for the conversion of $25 \mathrm{mM}$ of 1a to the corresponding amine (results in Table 3).

Table 3. Effect of surfactant on conversion plateau (\%). Reaction conditions: $25 \mathrm{mM}$ ketone 1a; $50 \mathrm{mM}(S)$-PEA; $50 \mathrm{mM}$ decane; $10 \mu \mathrm{L}$ of enzyme preparation (0.95 U) in HEPES buffer ( $\mathrm{pH} \mathrm{8.2,} 50 \mathrm{mM})$; $37^{\circ} \mathrm{C}$; isooctane: final volume $1 \mathrm{~mL}$.

\begin{tabular}{lllllllll}
\hline \multirow{2}{*}{ Surfactant } & \multicolumn{7}{c}{ Concentration [mM] } \\
\cline { 2 - 9 } & 1.0 & 2.5 & 5.0 & 10 & 25 & 50 & 75 & 100 \\
\hline Brij $^{\circledR}$ C10 & $<3$ & $<3$ & $<3$ & $<3$ & 6.5 & 65 & 25 & \\
Brij $^{\circledR} 58$ & 25 & 27 & 21 & 24 & 8.1 & 6.0 & 3.9 & 1.5 \\
Triton $^{\mathrm{TM}}$ - & 27 & & 20 & 22 & 10 & 8.2 & & \\
X100 & & & & & & & & \\
Tween 20 & 22 & & 25 & 15 & 6.1 & 11 & & \\
AOT & n.c. & n.c. & n.c. & n.c. & n.c. & n.c. & n.c. & n.c. \\
\hline
\end{tabular}

The use of Brij ${ }^{\circledR} \mathrm{C} 10$, at a concentration of $25 \mathrm{mM}$ or lower, did not result in any detectable conversion. However, a higher concentration $(50 \mathrm{mM})$ of the same surfactant gave acceptable results (65 \% conversion). A further increase in concentration is restricted by its solubility in isooctane at $37^{\circ} \mathrm{C}$. Conversely, all the other non-ionic surfactants (Brij ${ }^{\circledR}$ 58, Triton ${ }^{\mathrm{TM}}-\mathrm{X} 100$ and Tween 20) activated the reaction at very low concentrations (1-5 mM), but the achieved conversions were in all cases disappointing (3-27 \%). Moreover, any increase in the surfactant concentration led to a decrease in the conversion.

The use of AOT resulted in no conversion in all the performed experiments. Such a result is somehow surprising since AOT is the most common surfactant reported in the literature for enzymatic micellar systems. ${ }^{[11]}$

In order to explore the versatility of the disperse system, a library of 12 4,4-disubstituted cyclohexanones (Figure 6) was selected and employed.

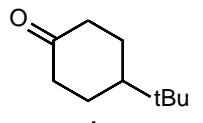

$1 \mathrm{a}$

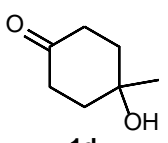

1d

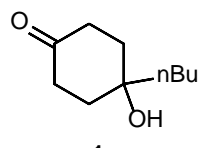

$1 \mathrm{~g}$

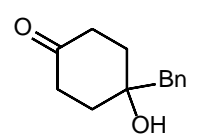

1j

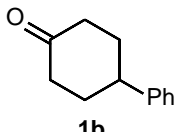

$1 b$
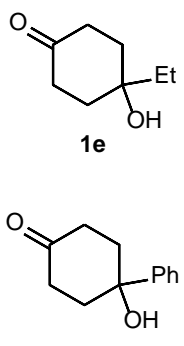

1h

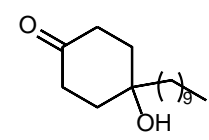

$1 \mathbf{k}$

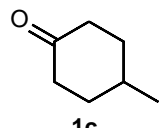

1c
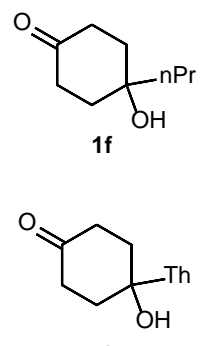

1i

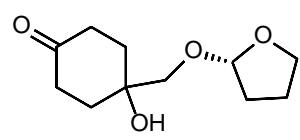

1)
Figure 6. Substrates library.

Ketones 1d-k are synthesized starting from the commercial precursor 1,4-cyclohexanedione monoethylene acetal (Scheme 4A). The latter is reacted with the appropriate Grignard reagent as the first step. Then, the protective group is easily removed by mild acid hydrolysis, and quantitative yields of the desired ketone (1d-k) are obtained after purification by flash chromatography or by distillation. 
A<smiles>[R11][C@H](C)OCC</smiles>

B

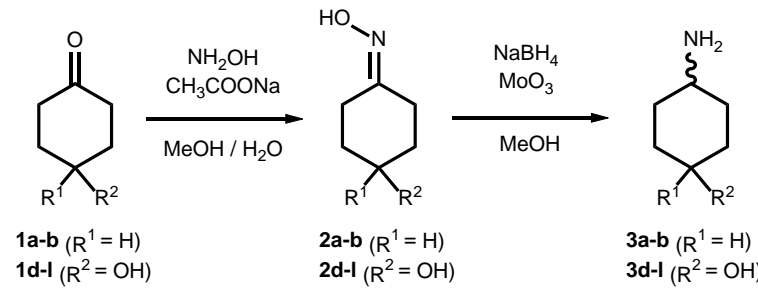

Scheme 4. A. Synthesis of ketones 1d-k. B. Metalmediated synthesis of the reference amines 3a-k.

Ketone $\mathbf{1 l}$ is a key intermediate for the synthesis of the antiviral drug Radalbuvir (also known as GS9669), ${ }^{[17]}$ and was kindly provided by Flamma SpA (Chignolo D’Isola, Italy).

Then, all the corresponding amines (3a-l) have been chemically synthesized through metal-mediated reductive amination in order to be employed as references for the enzymatic reaction (Scheme 4B), with the exception of amine $\mathbf{3 c}$, which is commercially available as a mixture of cis/trans. The ketones (1a-l) are reacted with hydroxylamine to form the oximes (2a-1), which are in turn reduced using $\mathrm{NaBH}_{4} / \mathrm{MoO}_{3}$ in methanol at $0{ }^{\circ} \mathrm{C} .{ }^{[10]}$ After the appropriate workup, the resulting amines (e) were pure enough for ${ }^{1} \mathrm{H}-\mathrm{NMR}$ characterization. Such reductive aminations result in mixtures of cis and trans isomers in a ratio varying from 60:40 to $95: 5$ (Table 4). The two isomers can be distinguished and quantified by ${ }^{1} \mathrm{H}-\mathrm{NMR}$ analysis as described in the SI. In total, four different enzymes were screened: $\mathrm{CV}$ ATA, ${ }^{[18]} C v$-ATA W60C, ${ }^{[19]}$ ATA from Vibrio fluvialis (Vf-ATA) and ATA 113 (a commercial ATA from Codexis $\left.{ }^{\circledR}\right)$. The W60C variant of $C V$-ATA shows an increased enantiospecificity for (S)-PEA compared to the wild type. The aforementioned library of ketones was explored using $25 \mathrm{mM}$ of substrate, $50 \mathrm{mM}$ of (S)-PEA, $50 \mathrm{mM}$ of decane, 50 $\mathrm{mM}$ of $\mathrm{Brij}^{\circledR} \mathrm{C} 10,1.0 \% \mathrm{v} / \mathrm{v}$ HEPES buffer solution (50 mM, pH 8.2) containing $0.95 \mathrm{U}$ of ATA.

Table 4. Observed stereoselectivity for the reduction of the oximes using $\mathrm{NaBH}_{4}$ and $\mathrm{MoO}_{3}$.

\begin{tabular}{ccc}
\hline Product & Cis [\%] & Trans [\%] \\
\hline 3a & 62 & 38 \\
3b & 59 & 41 \\
3d & 88 & 12 \\
$\mathbf{3 e}$ & 87 & 13 \\
$\mathbf{3 f}$ & 88 & 12 \\
$\mathbf{3 g}$ & 89 & 11 \\
$\mathbf{3 h}$ & 95 & 5 \\
$\mathbf{3 i}$ & 77 & 23 \\
$\mathbf{3 j}$ & 90 & 10 \\
$\mathbf{3 k}$ & 93 & 3 \\
$\mathbf{3 l}$ & 85 & 15 \\
\hline
\end{tabular}

The final volume of the reaction solutions was $1 \mathrm{~mL}$ using MTBE or isooctane as solvents.

The mixtures were vigorously shaken at $37{ }^{\circ} \mathrm{C}$ and left to react for 48 hours (results in Table 4). Despite the preliminary solvent exploration had shown that

Table 4. Biotransformations of 4,4-disubstituted-cyclohexanones: conversions and cis/trans ratios. Reaction conditions: 25 $\mathrm{mM}$ ketone; $50 \mathrm{mM}$ (S)-PEA; $50 \mathrm{mM}$ decane; $50 \mathrm{mM} \mathrm{Brij}{ }^{\circledR} \mathrm{C} 10 ; 10 \mu \mathrm{L}$ of enzyme preparation (0.95 U) in HEPES buffer (pH 8.2, $50 \mathrm{mM}$ ); isooctane or MTBE: final volume $1 \mathrm{~mL}$. (n.c. = no conversion).

\begin{tabular}{|c|c|c|c|c|c|c|c|c|c|c|}
\hline \multirow{2}{*}{ Substrate } & \multirow{2}{*}{ Solvent } & \multicolumn{3}{|c|}{$C v$-ATA } & \multicolumn{3}{|c|}{$C v$-ATA-W60 } & \multicolumn{3}{|c|}{$V f$-ATA } \\
\hline & & Conv. [\%] & Cis [\%] & Trans [\%] & Conv. [\%] & Cis [\%] & Trans [\%] & Conv. [\%] & Cis [\%] & Trans [\%] \\
\hline \multirow{2}{*}{ 1a } & MTBE & 50 & 98.6 & 1.4 & 15 & 98.7 & 1.3 & 3 & 98.6 & 1.4 \\
\hline & isooctane & 60 & 98.3 & 1.7 & - & - & - & 56 & 96.8 & 3.2 \\
\hline \multirow{2}{*}{$1 b$} & MTBE & 55 & 95.1 & 4.9 & 79 & 99.6 & 0.4 & 3 & 98.8 & 1.2 \\
\hline & isooctane & 83 & 97.6 & 2.6 & - & - & - & 80 & 95.7 & 4.3 \\
\hline \multirow{2}{*}{ 1c } & MTBE & 45 & 68.5 & 31.5 & 10 & 0.5 & 99.5 & 8 & 20.7 & 79.3 \\
\hline & isooctane & 70 & 21.0 & 79.0 & - & - & - & 85 & 37.0 & 63.0 \\
\hline \multirow{2}{*}{ 1d } & MTBE & 55 & 24.3 & 75.7 & 22 & 4.0 & 96.0 & 10 & 18.0 & 82.0 \\
\hline & isooctane & 28 & 12.1 & 87.9 & - & - & - & 30 & 7.1 & 92.9 \\
\hline \multirow{2}{*}{$1 e$} & MTBE & 50 & 1.7 & 98.3 & 21 & 0.9 & 99.1 & 13 & 7.7 & 92.3 \\
\hline & isooctane & - & - & - & - & - & - & 40 & 12.0 & 88.0 \\
\hline \multirow{2}{*}{ 1f } & MTBE & 60 & 1.5 & 98.5 & 26 & 0.6 & 99.4 & 14 & 1.8 & 98.2 \\
\hline & isooctane & - & - & - & - & - & - & 47 & 0.3 & 99.7 \\
\hline \multirow{2}{*}{$1 \mathrm{~g}$} & MTBE & 46 & 0.4 & 99.6 & 15 & 0.2 & 99.8 & 9 & $<0.1$ & $>99.9$ \\
\hline & isooctane & - & - & - & - & - & - & 50 & 0.2 & 99.8 \\
\hline
\end{tabular}




\begin{tabular}{clccccccccc}
$\mathbf{1 h}$ & MTBE & 58 & $<0.1$ & $>99.9$ & 33 & 0.6 & 99.4 & 3 & 0.4 & 99.6 \\
& isooctane & - & - & - & - & - & - & 50 & 0.2 & 99.8 \\
$\mathbf{1 i}$ & MTBE & 41 & 77.7 & 22.3 & 19 & 77.5 & 22.5 & 10 & 77.1 & 22.9 \\
& isooctane & - & - & - & - & - & - & 47 & 77.5 & 22.5 \\
\multirow{2}{*}{$\mathbf{1 j}$} & MTBE & 15 & 0.8 & 99.2 & 10 & 13.8 & 86.2 & 3 & 4.8 & 95.2 \\
& isooctane & - & - & - & - & - & - & 30 & 1.7 & 98.3 \\
\multirow{2}{*}{$\mathbf{1 k}$} & MTBE & n.c. & - & - & n.c. & - & - & 3 & 0.9 & 99.1 \\
& isooctane & n.c. & - & - & n.c. & - & - & 18 & 0.6 & 99.4 \\
$\mathbf{1 1}$ & MTBE & 35 & 7.1 & 92.9 & 22 & 0.6 & 99.4 & 14 & 0.5 & 99.5 \\
& isooctane & 15 & 2.7 & 97.3 & - & - & - & 29 & 0.2 & 99.8 \\
\hline
\end{tabular}


isooctane was the most suitable solvent for these reactions, some of the synthesized ketones are poorly soluble in this solvent, and only MTBE was employed. The reported conversions are measured after 48 hours. At the end of the reaction, the solution was cooled to $4{ }^{\circ} \mathrm{C}$, where phase separation occurs: the organic supernatant essentially contains both the remaining substrates and the products, whereas salts, the enzyme, the cofactor and most of the surfactant are collected in the aqueous phase.

When ATA 113 was employed, no conversions were detected in any case. However, interesting results were obtained with the other enzymes. In general, the explored enzymes showed high cis selectivity towards 4-monosubstituted-cyclohexanones, whereas 4-substituted-4-hydroxyl-cyclohexanones are selectively transformed into trans amines. This apparent switch of selectivity is simply due to nomenclature: as a matter of fact, both the groups have the 4-alkyl chain positioned on the same side of the cyclohexene ring with respect to the amino moiety (Figure 7).

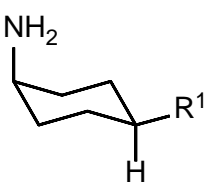

3a-c

cis isomer

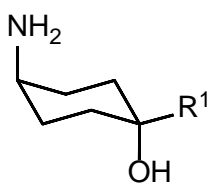

3d-I

trans isomer
Figure 7. Comparison of the structure of the two groups of amines obtained after biotransformation.

The selectivity of the ATAs towards ketone $\mathbf{1 i}$ is reversed, despite the similarity between phenyl and thienyl rings. In addition, the hydroxyl moiety seems not to affect the enzyme selectivity: In general, the biocatalytic approach leads to a good stereoselectivity. In addition, the ATA-catalyzed transaminations result in the production of the more unusual trans isomer as the major product, while the chemical approach using $\mathrm{NaBH}_{4}$ and $\mathrm{MoO}_{3}$ favors the cis isomer.

\section{Conclusion}

A novel approach for the use of ATAs in the transformation of hydrophobic substrates was developed and employed, carrying out the reductive amination of a library of 12 cyclic ketones. This approach involves the use of surfactants for obtaining a macroscopically homogeneous water-in-oil emulsion, where the enzymatic preparation is finely dispersed in the organic phase. Such a system was characterized with DLS analysis and different parameters were explored in order to optimize the process (e.g. temperature, solvents and type of surfactant). The highest conversions were obtained using isooctane or MTBE as solvent, Brij ${ }^{\circledR} \mathrm{C} 10$ as surfactant at $37{ }^{\circ} \mathrm{C}$ and $1.0 \% \mathrm{v} / \mathrm{v}$ of aqueous enzymatic preparation. Among the evaluated amino donors, only (S)-PEA was effective in this approach. Moreover, the solvent was proven to be an important parameter. MTBE dissolved the starting materials more efficiently than isooctane, even if the latter is better tolerated by the enzyme. In the end, this approach possesses many useful advantages. First of all, the use of organic solvents and surfactants permits to address the frequent solubility issues of hydrophobic substrates. At the same time, enzyme stability in the reaction mixture is remarkably high (more than a week), the reaction workup is easy and practical since it mainly consists in cooling the reaction mixture and centrifuging it in order to recover the final product. Lastly, this protocol can be easily employed with different substrates and ATAs.

\section{Experimental Section}

\section{Reagents and instruments}

All the necessary chemicals were purchased from SigmaAldrich. All solvents employed in reactions were of analytical grade and, where indicated, were dried on activated $4 \AA$ molecular sieves prior to use. The solvents employed in HPLC analysis were of HPLC grade and the prepared eluents were filtered through a $0.45 \mu \mathrm{m}$ membrane prior to use. Silica gel 60 F254 plates (Merck) were used for analytical TLC. Detection was achieved with UV light followed by ninhydrin, potassium permanganate, or cerium molybdate stains.

HPLC analyses were performed on a Jasco apparatus equipped with a diode array detector and a fluorimeter, fitted with a Kinetex $2.6 \mu \mathrm{m}$ C18 $100 \AA$ column, length/internal diameter $=100 / 4.6 \mathrm{~mm}$ (Phenomenex). The excitation and emission wavelengths for fluorescence detection were $350 \mathrm{~nm}$ and $450 \mathrm{~nm}$, respectively.

${ }^{1} \mathrm{H}$ and ${ }^{13} \mathrm{C}-\mathrm{NMR}$ spectra were recorded on Bruker ARX 400 instrument operating at the ${ }^{1} \mathrm{H}$ resonance frequency of $400 \mathrm{MHz}$. Chemical shifts (d, ppm) are reported relative to tetramethylsilane (TMS) as the internal standard. All spectra were recorded in $\mathrm{CDCl}_{3}$ or DMSO-d $\mathrm{d}_{6}$ at $305 \mathrm{~K}$. Coupling constants $(J)$ are reported in Hz. Mass spectra were acquired on BRUKER Esquire 3000 PLUS equipped with ESI Ion Trap LC/MS System.

GC-FID analyses were performed on a Hewlett Packard 5890 Series II gas chromatography apparatus equipped with a CP-ChiraSil-DEX CB $25 \mathrm{~m}$ x $0.32 \mathrm{~mm}$ x $0.25 \mathrm{~mm}$ or Chrompack CP-SIL 5CB column (25 m x $0.32 \mathrm{~mm})$. The inlet and the detector were set to $250{ }^{\circ} \mathrm{C}$. The following method was used: initial temperature $100{ }^{\circ} \mathrm{C}$, hold for $0.5 \mathrm{~min}, 10^{\circ} \mathrm{C} \mathrm{m^{-1 }}$ to $200^{\circ} \mathrm{C}$ and hold $2-25 \mathrm{~min}$.

UV spectra and absorbance measurements were performed on a Jasco V-560 UV/VIS spectrophotometer.

Dynamic light scattering (DLS) measurements were conducted on a Zetasizer Nano ZS instrument (Malvern, UK), at $37^{\circ} \mathrm{C}$, with an equilibration time of $120 \mathrm{~s}$. 


\section{HPLC Conditions}

The HPLC analyses of the cyclohexylamine derivatives were performed after derivatization with ophthaldialdehyde (OPA) and $N$-protected-L-cysteine ( $N$ acetyl-L-cysteine or $N$-tert-butyloxycarbonyl-L-cysteine, respectively NAC and TBC) ${ }^{[20]}$ The OPA-NAC reagent was prepared by dissolving $8 \mathrm{mg}$ of OPA and $10 \mathrm{mg}$ of NAC in $1 \mathrm{~mL}$ of HPLC grade methanol, while OPA-TBC was prepared by dissolving $10 \mathrm{mg}$ of OPA and $10 \mathrm{mg}$ of TBC in $1 \mathrm{~mL}$ of HPLC grade methanol. Derivatizations were performed by adding $175 \mu \mathrm{L}$ of borate buffer $(0.4 \mathrm{M}$, $\mathrm{pH} 10.4$ ) to $25 \mu \mathrm{L}$ of samples and then adding $50 \mu \mathrm{L}$ of OPA-NAC or OPA-TBC reagent. The samples were left to react for 1 minute in the dark before the injection. Due to the different nature of each amine, different HPLC conditions were employed; these are summarized in Table 5.

Table 5. HPLC running conditions for the analysis of the produced amines, after derivatization. A: acetate buffer 10 $\mathrm{mM}$ pH 5.2 (45\%), $\mathrm{MeOH}$ (55\%); B: $\mathrm{MeOH}$ (100\%); C: acetate buffer pH 5.2 (95\%), $\mathrm{MeOH}$ (5\%)

\begin{tabular}{cccccccc}
\hline & $\begin{array}{c}\text { Derivatizing } \\
\text { agent }\end{array}$ & $\begin{array}{c}\text { Flow } \\
{[\mathrm{mL}} \\
\left.\mathrm{min}^{-1}\right]\end{array}$ & $\begin{array}{c}\mathrm{A} \\
{[\%]}\end{array}$ & $\begin{array}{c}\mathrm{B} \\
{[\%]}\end{array}$ & $\begin{array}{c}\mathrm{C} \\
(\%)\end{array}$ & $\begin{array}{c}\text { Cis } \\
\text { r.t. } \\
{[\mathrm{min}]}\end{array}$ & $\begin{array}{c}\text { Trans } \\
\text { r.t. } \\
{[\mathrm{min}]}\end{array}$ \\
\hline 3a & OPA-NAC & 0.85 & 87 & 13 & - & 22.9 & 23.9 \\
$\mathbf{3 b}$ & OPA-NAC & 0.5 & 92.5 & 7.5 & - & 34.1 & 36.1 \\
$\mathbf{3 c}$ & OPA-TBC & 0.85 & 87 & 13 & & 26.7 & 24.2 \\
& & & & & & & \\
3d & OPA-TBC & 0.5 & 100 & - & - & 9.4 & 18.5 \\
3e & OPA-TBC & 0.5 & 100 & - & - & 13.1 & 28.3 \\
3f & OPA-NAC & 0.5 & 100 & - & - & 5.4 & 13.0 \\
3g & OPA-NAC & 0.5 & 100 & - & - & 9.2 & 27.2 \\
3h & OPA-NAC & 0.5 & 92.5 & 7.5 & - & 4.6 & 9.2 \\
3i & OPA-NAC & 0.5 & 92.5 & - & 7.5 & 7.5 & 16.1 \\
3j & OPA-NAC & 0.5 & 92.5 & 7.5 & - & 6.1 & 14.2 \\
3k & OPA-NAC & 0.85 & 70 & 30 & - & 13.9 & 42.3 \\
3l & OPA-TBC & 0.5 & 100 & - & - & 10.6 & 16.2 \\
\hline
\end{tabular}

\section{4-methyl-4-hydroxycyclohexanone (1d).}

An ethereal solution $(30 \mathrm{~mL})$ of $\mathrm{CH}_{3} \mathrm{I}(598 \mu \mathrm{L}, 9.6 \mathrm{mmol})$ was added dropwise to a suspension of $\mathrm{Mg}$ turnings (233 $\mathrm{mg}, 9.6 \mathrm{mmol})$ in dry diethyl ether $(2.5 \mathrm{~mL})$ under vigorous stirring. The mixture was left to react at r.t. (a reflux condenser was added in order to control the reaction and prevent solvent evaporation) until complete dissolution of Mg; then, a solution of 1,4-cyclohexanedionone monoethylene ketal (1.5 g, $9.6 \mathrm{mmol})$ in dry diethyl ether (30 mL) was gradually added to the reaction mixture. The consumption of the ketone was followed by TLC. When the ketone was completely consumed, $25 \mathrm{~mL}$ of water were added to the reaction, the organic phase was separated and the aqueous phase was extracted with diethyl ether (2x30 mL). The organic phase was dried over anh. $\mathrm{Na}_{2} \mathrm{SO}_{4}$ and evaporated under reduced pressure obtaining $1.36 \mathrm{~g}$ of a pale yellow oil. $25 \mathrm{~mL}$ of aqueous $0.05 \mathrm{M} \mathrm{HCl}$ were added to the product and the resulting mixture was stirred overnight at r.t. When the hydrolysis was complete the reaction medium was saturated with $\mathrm{NH}_{4} \mathrm{Cl}$ and then extracted with AcOEt (4x25 mL). The organic phase was dried over $\mathrm{Na}_{2} \mathrm{SO}_{4}$ and evaporated under reduced pressure. The obtained pale yellow oil was purified by flash chromatography (AcOEt/Hexane/MeOH 2/8/0.1) obtaining $790 \mathrm{mg}$ of a white solid corresponding to compound 1d in $64 \%$ yield. ${ }^{1} \mathrm{H}$ NMR $\left(\mathrm{CDCl}_{3}\right): 1.33(\mathrm{~s}, 3 \mathrm{H}), 1.61(\mathrm{~s}, 1 \mathrm{H})$, 1.75-1.87 (dt, 2H, $J=5,13.3), 1.89-1.98(\mathrm{~m}, 2 \mathrm{H}), 2.15-2.24$ (m, 2H), 2.70-2.74 (m, 2H).

According to the procedure described above, and starting from 1,4-cyclohexanedionone monoethylene ketal and the opportune alkyl chloride or bromide, the following ketones were synthesized. Yields are calculated based on the starting ketale.

\section{4-ethyl-4-hydroxycyclohexanone (1e).}

Yield $48.0 \%$.

1H-NMR ( $\left.\mathrm{CDCl}_{3}\right): 0.90-0.97$ (t, 3H, $\left.J=7.5\right), 1.39$ (s, 1H), $1.52-1.62$ (q, 2H, $J=7.5), 1.70-1.80$ (dt, $2 \mathrm{H}, J=5.1,8.4$ ), 1.87-1.95 (m, 2H), 2.17-2.25 (m, 2H), 2.63-2.74 (m, 2H).

\section{4-hydroxy-4-propylcyclohexanone (1f). \\ Yield $16.7 \%$.}

${ }^{1} \mathrm{H}-\mathrm{NMR}\left(\mathrm{CDCl}_{3}\right): 0.91-0.97(\mathrm{t}, 3 \mathrm{H}, J=7.2), 1.34-1.56(\mathrm{~m}$, $5 \mathrm{H}), 1.71-1.83(\mathrm{~m}, 2 \mathrm{H}), 1.88-1.97(\mathrm{~m}, 2 \mathrm{H}), 2.18-2.26(\mathrm{~m}$, $2 \mathrm{H}), 2.64-2.65$ (m, 2H).

\section{4-butyl-4-hydroxycyclohexanone (1g). \\ Yield $24.0 \%$.}

${ }^{1} \mathrm{H}-\mathrm{NMR}\left(\mathrm{CDCl}_{3}\right): 0.88-0.94$ (t, 3H, J=7.4), 1.26-1.42 (m, $5 \mathrm{H}), 1.51-1.57$ (m, 2H), 1.76-1.82 (dt, 2H, $J=5.2,13.1$ ) 1.88-1.97 (m, 2H), 2.17-2.24 (m, 2H), 2.64-2.73 (m, 2H) ${ }^{13} \mathrm{C} \mathrm{NMR}\left(\mathrm{CDCl}_{3}\right): 13.88,23.10,25.53,36.76,36.94$, 42.22, 70.03, 212.40.

\section{4-phenyl-4-hydroxycyclohexanone (1h).}

Yield 33.0\%

${ }^{1} \mathrm{H}-\mathrm{NMR}\left(\mathrm{CDCl}_{3}\right): 1.722$ (s, 1H), 2.17-2.26 (m, 2H), 2.29$2.52(\mathrm{~m}, 4 \mathrm{H}), 2.87-3.00$ (dt, 2H, $J=5.2,13.7), 7.29-7.34$ (d, $1 \mathrm{H}, J=7.29), 7.38-7.43$ (t, $2 \mathrm{H}, J=7.32), 7.53-7.56$ (d, $2 \mathrm{H}$, $J=7.29$ )

\section{4-hydroxy-4-(thiophen-2-yl)cyclohexanone (1i). \\ Yield $53.0 \%$}

${ }^{1} \mathrm{H}-\mathrm{NMR}\left(\mathrm{CDCl}_{3}\right): 2.18-2.35$ (m, 4H), 2.70-2.85 (m, 4H) 6.89-6.93 (m, 1H), 6.95-6.98 (dd, $1 \mathrm{H}, J=1.2,3.6), 7.16$ 7.20 (dd, $1 \mathrm{H}, J=1.2,5.0)$. ${ }^{13} \mathrm{C} \mathrm{NMR}\left(\mathrm{CDCl}_{3}\right): 37.22,39.38$, 70.58, 122.54, 124.38, 126.88, 152.15, 211.10.

\section{4-benzyl-4'-hydroxyl-cyclohexanone (1j).}

Yield $30.0 \%$

${ }^{1} \mathrm{H}-\mathrm{NMR}\left(\mathrm{CDCl}_{3}\right): 1.74-1.93(\mathrm{~m}, 5 \mathrm{H}), 2.13-2.22(\mathrm{~m}, 2 \mathrm{H})$ $2.57-2.68(\mathrm{~m}, 2 \mathrm{H}), 2.80(\mathrm{~s}, 2 \mathrm{H}), 7.14-7.30(\mathrm{~m}, 5 \mathrm{H}) .{ }^{13} \mathrm{C}$ NMR $\left(\mathrm{CDCl}_{3}\right): 36.79,36.85,48.63,69.86,126.90,128.44$, $130.39,136.40,211.78$.

\section{4-decyl-4'-hydroxyl-cyclohexanone (1k).}

Yield $40.0 \%$

${ }^{1} \mathrm{H}-\mathrm{NMR}\left(\mathrm{CDCl}_{3}\right)$ : 0.84-0.88 (t, 3H, J=6.7), 1.14-1.42 (m, $17 \mathrm{H}), 1.49-1.56(\mathrm{~m}, 2 \mathrm{H}), 1.71-1.82(\mathrm{dt}, 2 \mathrm{H}, J=5.2,13.5)$, 1.88-1.97 (m, 2H), 2.17-2.26 (m, 2H), 2.62-2.75 (m, 2H). ${ }^{13} \mathrm{C}$ NMR $\left(\mathrm{CDCl}_{3}\right): 14.23,22.58,23.69,29.23,29.51$, 30.08, 31.82, 36.84, 36.96, 42.60, 70.21, 212.01.

\section{4-amino-1-methylcyclohexan-1-ol (3d).}

A mixture of 1d (70 mg, $0.55 \mathrm{mmol})$, hydroxylamine hydrochloride $(57 \mathrm{mg}, 0.82 \mathrm{mmol})$, sodium acetate $(90 \mathrm{mg}$ $1.09 \mathrm{mmol})$, water $(1 \mathrm{~mL})$ and $\mathrm{MeOH}(4.5 \mathrm{~mL})$ was stirred at r.t. for $1 \mathrm{~h}$. Most of the solvent was evaporated under reduced pressure; the residue was resuspended in $5 \mathrm{~mL}$ water and extracted with AcOEt $(4 \times 10 \mathrm{~mL})$. The combined organic fractions were dried over $\mathrm{NaSO}_{4}$ and the solvent distilled off to give $79 \mathrm{mg}$ of the corresponding oxime as a white solid, which was used in the next reactions without purification. To the obtained oxime, dissolved in $\mathrm{MeOH}(25 \mathrm{~mL}), \mathrm{MoO}_{3}$ was added and the resulting mixture was stirred at $0{ }^{\circ} \mathrm{C}$. Then, $\mathrm{NaBH}_{4}(209$ $\mathrm{mg}, 5.52 \mathrm{mmol}$ ) was portion-wise added in 2 hours. The depletion of the oxime was followed by TLC. When the substrate was completely consumed, the solvent was evaporated under reduced pressure and the residue was suspended in ethyl acetate $(10 \mathrm{~mL})$; a solution of ammonium hydroxide $(1 \mathrm{M}, 5 \mathrm{~mL})$ was added and the resulting mixture was filtered through a Celite pad. After phase separation, the aqueous phase was saturated with $\mathrm{NaCl}$ and extracted with AcOEt (4 x $10 \mathrm{~mL})$. The combined organic fractions were dried over $\mathrm{Na}_{2} \mathrm{SO}_{4}$ and the solvent distilled off to obtain $50 \mathrm{mg}$ of a white solid 
(yield $70.8 \%$ ), which is a mixture of cis/trans isomer of the compound 3d.

Yield 96\%

${ }^{1} \mathrm{H}$ NMR (CDCl3): 1.13-1.20 (m, 3H), 1.30-1.79 (m, 9H), 2.50-2.59 (m, $1 \mathrm{H}$, cis isomer), 2.70-2.80

(m, $1 \mathrm{H}$, trans isomer). ESI-MS m/z $130[\mathrm{M}+\mathrm{H}+]$.

According to the procedure described above and starting from the corresponding ketones, the following amines were synthetized. Yields are calculated based on the starting ketone.

\section{4-tert-butyl-cyclohexyl-1-amine (3a).}

${ }^{1} \mathrm{H}-\mathrm{NMR}\left(\mathrm{CDCl}_{3}\right): 0.83-0.86$ (s, 9H), 0.91-1.13 (m, 5H),

1.58.1.97 (m, 6H), 2.50-2.62 (m, $1 \mathrm{H}$, trans isomer), 2.79-

$2.92\left(\mathrm{~m}, 1 \mathrm{H}\right.$, cis isomer). ESI-MS m/z $156\left[\mathrm{M}+\mathrm{H}^{+}\right]$.

\section{4-phenyl-cyclohexyl-1-amine (3b). \\ Yield 95\%}

${ }^{1} \mathrm{H}-\mathrm{NMR}\left(\mathrm{CDCl}_{3}\right): 1.19-1.29(\mathrm{~m}, 2 \mathrm{H}), 1.46-1.63(\mathrm{~m}, 4 \mathrm{H})$, 1.86-2.02 (m, 4H), 2.42-2.52 (m, 1H), 2.59-2.69 (m, 1H, trans isomer), 2.96-3.04 (m, $1 \mathrm{H}$, cis isomer), 7.12-7.35 (m, $5 \mathrm{H})$. ESI-MS m/z $176\left[\mathrm{M}+\mathrm{H}^{+}\right]$

\section{4-amino-1-ethylcyclohexan-1-ol (3e).}

Yield 92\%

${ }^{1} \mathrm{H}-\mathrm{NMR}$ (CDCl3): 0.81-0.87 (t, 3H, J=7.5), 1.24-1.68 (m, $14 \mathrm{H}), 2.51-2.60(\mathrm{~m}, 1 \mathrm{H}$, cis isomer), $2.76-2.84(\mathrm{~m}, 1 \mathrm{H}$, trans isomer). ESI-MS m/z $144\left[\mathrm{M}+\mathrm{H}^{+}\right]$.

\section{4-amino-1-propylcyclohexan-1-ol (3f). \\ Yield 90\%}

${ }^{1} \mathrm{H}-\mathrm{NMR}\left(\mathrm{CDCl}_{3}\right): 0.80-0.91$ (m, 3H), 1.15-1.80 (m, 16H), 2.53-2.63 (m, $1 \mathrm{H}$, cis isomer $), 2.75-2.85(\mathrm{~m}, 1 \mathrm{H}$, trans isomer). ESI-MS m/z $158\left[\mathrm{M}+\mathrm{H}^{+}\right]$.

\section{4-amino-1-butylcyclohexan-1-ol (3g).}

Yield 91\%

${ }^{1} \mathrm{H}-\mathrm{NMR}\left(\mathrm{CDCl}_{3}\right)$ : 0.82-0.94 (m, 3H), 1.12-1.86 (m, 18H), 2.52-2.64 (m, $1 \mathrm{H}$, cis isomer $), 2.85-2.97(\mathrm{~m}, 1 \mathrm{H}$, trans isomer). ESI-MS m/z $172\left[\mathrm{M}+\mathrm{H}^{+}\right]$.

\section{4-amino-1-phenylcyclohexan-1-ol (3h).}

Yield 95\%

${ }^{1} \mathrm{H}-\mathrm{NMR}$ (DMSO-d 6 ): 1.54-1.87 (m, 9H), 2.64-2.70 (m, $1 \mathrm{H}$, cis isomer), 7.05-7.11 (t, 1H, $J=7.3), 7.17-7.23(\mathrm{t}, 2 \mathrm{H}$, $J=7.3), 7.35-7.40(\mathrm{~d}, 2 \mathrm{H}, J=8.1)$. ESI-MS m/z $192[\mathrm{M}+$ $\left.\mathrm{H}^{+}\right]$.

\section{4-amino-1-(thiophen-2-yl)cyclohexan-1-ol (3i).}

Yield 89\%

${ }^{1} \mathrm{H}-\mathrm{NMR}$ (DMSO- $\mathrm{d}_{6}$ ): 1.51-1.70 (m, 4H), 1.71-1.82 (td, $2 \mathrm{H}, J=4.2,13.4) 1.88-1.95(\mathrm{~m}, 2 \mathrm{H}), 2.59-2.69(\mathrm{~m}, 1 \mathrm{H}$, cis isomer), 2.74-2.82 (m, $1 \mathrm{H}$, trans isomer), $2.61(\mathrm{~s}, 2 \mathrm{H})$, 2.58-2.65 (m, $1 \mathrm{H}$, trans isomer), 6.80-6.84 (dd, $1 \mathrm{H}, \mathrm{J}=3.6$, 4.9), 6.84-6.87 (dd, $1 \mathrm{H}, J=1.2,3.6$ ), 7.09-7.11 (dd, $1 \mathrm{H}$, $J=1.2$, 4.9). ESI-MS m/z $198\left[\mathrm{M}+\mathrm{H}^{+}\right]$.

\section{4-amino-1-benzylcyclohexan-1-ol (3j). \\ Yield 96\%}

${ }^{1} \mathrm{H}-\mathrm{NMR}$ (DMSO-d $\mathrm{d}_{6}$ ): 1.16-1.65 (m, 11H), 2.38-2.47 (m, $1 \mathrm{H}$, cis isomer), 7.01-7.17 (m, 5H). ESI-MS m/z $206[\mathrm{M}+$ $\mathrm{H}^{+}$.

\section{4-amino-1-decylcyclohexan-1-ol (3k). \\ Yield 65\% \\ ${ }^{1} \mathrm{H}-\mathrm{NMR}\left(\mathrm{CDCl}_{3}\right): 0.87-0.92(\mathrm{t}, 3 \mathrm{H}, J=6.7), 1.22-1.95(\mathrm{~m}$, $29 \mathrm{H}$ ), 2.87-2.97 (m, 1H, cis isomer). ESI-MS m/z 256 [M $\left.+\mathrm{H}^{+}\right]$.}

\section{4-amino-1-(((tetrahydrofuran-2- yl)oxy)methyl)cyclohexan-1-ol (31).}

Yield 61\%

${ }^{1} \mathrm{H}-\mathrm{NMR}\left(\mathrm{CDCl}_{3}\right): 1.28-1.38(\mathrm{td}, 2 \mathrm{H}, J=3.6,13.0), 1.46-$ 1.58 (qd, $2 \mathrm{H}, J=3.3,12.5,23.7)$, $1.66-1.75(\mathrm{~m}, 4 \mathrm{H}), 1.87-$
1.94 (bs, 3H), 1.95-2.01 (m, 2H), 2.58-2.68 (m, 1H), 3.193.27 (q, 2H, J=8.8), 3.75-3.91 (m, 4H), 4.09-4.14 (m, 1H). ESI-MS m/z $216\left[\mathrm{M}+\mathrm{H}^{+}\right]$.

\section{Enzymes preparation.}

The genes encoding for the $C v$-ATA-wt, $C v$-ATA-W60C Cv-ATA-F88A/A231F, Cv-ATA-W60C/F88A/A231F and $V f$-ATA were inserted in a pET28a(+) vector including an $N$-terminal His 6 -tag. The plasmids were transferred to the host BL21(DE3) Escherichia coli strain. Cells were grown at $37^{\circ} \mathrm{C}$ in TB medium (Terrific Broth) supplemented with $50 \mathrm{mg} / \mathrm{L}$ kanamycin. Protein expression was induced at an $\mathrm{OD}_{600} \sim 0.7-0.9$ by addition of IPTG $(1 \mathrm{mM})$. After $24 \mathrm{~h}$ of incubation at $20^{\circ} \mathrm{C}$ and $220 \mathrm{rpm}$, the cells were harvested by centrifugation (30 min, $8000 \mathrm{rpm}, 4^{\circ} \mathrm{C}$ ) and resuspended in IMAC binding buffer $\left(50 \mathrm{mM} \mathrm{NaH} \mathrm{PO}_{4}\right.$, $300 \mathrm{mM} \mathrm{NaCl}, 10 \mathrm{mM}$ imidazole, pH 8.0). The cells were disrupted by sonication and the cell debris was removed by centrifugation (30 min, $20,000 \mathrm{rpm}, 4{ }^{\circ} \mathrm{C}$ ) followed by filtration $(0.45 \mu \mathrm{m})$. The purification process was performed on a Ni-NTA Sepharose column. For $\mathrm{Cv}$-ATAwt, Cv-ATA-F88A/A231F and Vfl-ATA the fraction containing ATA activity was dialyzed against HEPES buffer $(50 \mathrm{mM}, \mathrm{pH}$ 8.2) on a PD10 column (GE Healthcare), according to the manufacturer's protocol. After addition of PLP ( $3 \mathrm{mM})$, the enzyme was incubated for $24 \mathrm{~h}$ at $4{ }^{\circ} \mathrm{C}$. Thereafter, it was dialyzed against HEPES buffer ( $50 \mathrm{mM}$, pH 8.2) to remove the excess of PLP, after incubation at $37{ }^{\circ} \mathrm{C}$ for 1 h. For $C v$-ATAW60C/F88A/A231F and CV-ATA-W60C the same procedure was applied using HEPES buffer $(50 \mathrm{mM}, \mathrm{pH}$ 7.0). The protein concentration of the enzyme preparation was estimated by absorbance at $280 \mathrm{~nm}$. The enzyme was stored at $4{ }^{\circ} \mathrm{C}$ and was incubated for $30 \mathrm{~min}$ at $37^{\circ} \mathrm{C}$ prior to using.

Surfactant-protected lyophilized enzyme powders were prepared as follows: the surfactants, Brij ${ }^{\circledR} \mathrm{C} 10$ (15 mg) and octyl- $\beta$-D-glucopyranoside (15 mg), were dissolved in 3 $\mathrm{mL}$ HEPES buffer $(50 \mathrm{mM}, \mathrm{pH} 8.2)$ at $37^{\circ} \mathrm{C}$. Then, the enzyme was added ( $3 \mathrm{~mL}, 6 \mathrm{mg} / \mathrm{mL}$ ). After mixing, the solution was rapidly frozen in liquid $\mathrm{N}_{2}$ and lyophilized for the established time. For side-to-side comparison, half of the enzyme batch was lyophilized without the addition of surfactants.

The enzymatic activity was assayed spectrophotometrically at $25{ }^{\circ} \mathrm{C}$ by monitoring the formation of acetophenone from PEA; $1 \mathrm{~mL}$ of reaction mixture containing $2 \mu \mathrm{g}$ (or $150 \mu \mathrm{g}$ ) enzyme, $2.5 \mathrm{mM}$ PEA ( $S$ or $R$ depending of the enantiopreference of the enzyme), $2.5 \mathrm{mM}$ pyruvate and HEPES buffer (50 mM, pH 8.2) was used. The reaction was monitored for 2 min following the absorbance increase at $245 \mathrm{~nm}\left(\varepsilon=12 \mathrm{mM}^{-1} \mathrm{~cm}^{-1}\right)$. Activity: one unit $(1 \mathrm{U})$ was defined as the amount of enzyme converting $1 \mu$ mol of PEA in $1 \mathrm{~min}$.

\section{Biotransformations in neat solvents.}

The solvents were dried over molecular sieves ( $4 \AA$ ) before use. $20 \mathrm{mg}$ lyophilized $C v$-ATA-wt, $(S)$-PEA $(50 \mathrm{mM})$, compound 1a $(150 \mathrm{mM})$ and decane $(50 \mathrm{mM})$ were dissolved together in dry isooctane $(1 \mathrm{~mL})$. Conversions were evaluated by GC-FID following the concentration of acetophenone while the cis/trans ratio of the formed amine was evaluated by HPLC. For the GC-FID, $20 \mu \mathrm{L}$ samples were diluted in $0.5 \mathrm{~mL}$ of cyclohexane and then injected without further derivatization. HPLC analysis was performed at the end of each experiment; the reaction medium was evaporated under reduced pressure, then about $2.5 \mathrm{mg}$ of the residue was dissolved in $1 \mathrm{~mL} \mathrm{HCl}$ $0.05 \mathrm{M}$. The resulting solution was analyzed as previously described.

\section{Biotransformations in disperse systems.}

The dry solvent (isooctane or MTBE) was heated at $37^{\circ} \mathrm{C}$, then the surfactant $(50 \mathrm{mM})$ was added and dissolved; the ketone (25 mM), (S)-PEA (50 mM), decane (50 mM) and, 
at the end, the enzymatic solution (1 \% v/v) were sequentially added. $10 \mu \mathrm{L}$ of enzymatic preparation contains $0.95 \mathrm{U}$ of the desired $\Omega$-TA dissolved in HEPES buffer $(50 \mathrm{mM}$, pH 8.2 or 7.0 in the function of the enzyme). This solution was incubated at $37^{\circ} \mathrm{C}$ for at least 30 minutes before use. The reaction mixture is then vigorously shaken. Conversions were evaluated by GCFID following the concentration of acetophenone while the cis/trans ratio of the formed amine was evaluated by HPLC. For the GC-FID $20 \mu \mathrm{L}$ samples were diluted in 0.5 $\mathrm{mL}$ cyclohexane and then injected without any further derivatization. HPLC analyses were performed at the end of each experiment: the reaction medium was evaporated under reduced pressure, then about $2.5 \mathrm{mg}$ of the residue was dissolved in $1 \mathrm{~mL} \mathrm{HCl} 0.05 \mathrm{M}$. The resulting solution was analyzed as previously described.

When the product isolation was needed, at the end of the reaction, the solution was brought at $4{ }^{\circ} \mathrm{C}$, and after $30 \mathrm{~min}$ was centrifuged to facilitate the phase separation: the supernatant was evaporated and the residue was purified by column chromatography.

\section{Acknowledgements}

The authors wish to deeply thank Prof. Francesca BaldelliBombelli (Politecnico di Milano) for DLS experiments and Flamma SpA (Chignolo d'Isola, ITALY) for the kind gift of substrate 11a.

This project was carried out in the frame of the COST Action CM1303 "SysBiocat" and dr. Fiorati could benefit from the funding for a "Short Term Scientific Mission" in prof. Berglund's laboratories.

\section{References}

[1] F. Gallou, B. Han, J. Lu, M. Seeger-Weibel, A.-F. Stoessel, S. Allmendinger, Tetrahedron Letters 2010, 51, 1419-1422.

[2] a) F. G. Mutti, W. Kroutil, Advanced Synthesis \& Catalysis 2012, 354, 3409-3413; b) Y. Satyawali, E. Ehimen, L. Cauwenberghs, M. Maesen, P. Vandezande, W. Dejonghe, Biochemical Engineering Journal 2017, 117, 97-104.

[3] C. K. Savile, J. M. Janey, E. C. Mundorff, J. C. Moore, S. Tam, W. R. Jarvis, J. C. Colbeck, A. Krebber, F. J. Fleitz, J. Brands, P. N. Devine, G. W. Huisman, G. J. Hughes, Science 2010, 329, 305-309.

[4] M. D. Truppo, H. Strotman, G. Hughes, ChemCatChem 2012, 4, 1071-1074.
[5] a) W. Neto, M. Schürmann, L. Panella, A. Vogel, J. M. Woodley, Journal of Molecular Catalysis B: Enzymatic 2015, 117, 54-61; b) M. D. Patil, G. Grogan, A. Bommarius, H. Yun, Catalysts 2018, 8, 254.

[6] J. F. Kirsch, G. Eichele, G. C. Ford, M. G. Vincent, J. N. Jansonius, H. Gehring, P. Christen, Journal of molecular biology 1984, 174, 497-525.

[7] C. S. Fuchs, R. C. Simon, W. Riethorst, F. Zepeck, W. Kroutil, Bioorganic \& Medicinal Chemistry 2014, 22, 5558-5562.

[8] E. Siirola, F. G. Mutti, B. Grischek, S. F. Hoefler, W. M. F. Fabian, G. Grogan, W. Kroutil, Advanced Synthesis \& Catalysis 2013, 355, 17031708.

[9] S. Chen, H. Land, P. Berglund, M. S. Humble, Journal of Molecular Catalysis B: Enzymatic 2016, 124, 20-28.

[10] J. Ipaktschi, Chemische Berichte 1984, 117, 856858.

[11] P. L. Luisi, Angewandte Chemie International Edition 1985, 24, 439-450.

[12] M. Pera-Titus, L. Leclercq, J. M. Clacens, F. De Campo, V. Nardello-Rataj, Angew Chem Int Edit 2015, 54, 2006-2021.

[13] P. Tufvesson, J. Lima-Ramos, J. S. Jensen, N. AlHaque, W. Neto, J. M. Woodley, Biotechnol Bioeng 2011, 108, 1479-1493.

[14] U. Kaulmann, K. Smithies, M. E. Smith, H. C. Hailes, J. M. Ward, Enzyme and microbial technology 2007, 41, 628-637.

[15] U. Schell, R. Wohlgemuth, J. M. Ward, Journal of Molecular Catalysis B: Enzymatic 2009, 59, 279-285.

[16] S. Chen, J. C. Campillo-Brocal, P. Berglund, M. S. Humble, J Biotechnol 2018, 282, 10-17.

[17] S. E. Lazerwith, W. Lew, J. Zhang, P. Morganelli, Q. Liu, E. Canales, M. O. Clarke, E. Doerffler, D. Byun, M. Mertzman, Journal of medicinal chemistry 2013, 57, 1893-1901.

[18] K. E. Cassimjee, M. S. Humble, V. Miceli, C. G. Colomina, P. Berglund, ACS Catalysis 2011, 1 , 1051-1055.

[19] K. E. Cassimjee, M. S. Humble, H. Land, V. Abedi, P. Berglund, Organic \& Biomolecular Chemistry 2012, 10, 5466-5470.

[20] Y. Mutaguchi, T. Ohshima, Biochemistry 2014, 4. 


\section{FULL PAPER}

Title Text

Adv. Synth. Catal. Year, Volume, Page - Page

TOC Graphic

Author(s), Corresponding Author(s)* 